\title{
METHODS FOR EVALUATING THE USE OF DIFFERENT APPROACHES OF ORGANIZING THE PROCESS OF TEACHING STUDENTS
}

\author{
Viktorija Ziborova \\ Riga Technical University, Latvia \\ Sabina Katalınikova \\ Riga Technical University, Latvia \\ Diana Zagulova \\ Baltic International Academy, Latvia \\ Natalya Prokofjeva \\ Riga Technical University, Latvia
}

\begin{abstract}
Control over any process of human activity is carried out by evaluating its result. In the field of education, the goal is, as a rule, to check the effectiveness of one or another pedagogical approach to solving the set task. For this purpose, a pedagogical experiment is planned and carried out. First, the analysis of the problem is carried out and the participants of the experiment are determined, control and experimental groups of approximately equal number and level of preparedness are formed. Further, the researched pedagogical approach is implemented, the results obtained are studied and evaluated, and conclusions are drawn. Research was conducted at the Department of Software Engineering and involved its students, as well as teachers of Riga Technical University and Baltic International Academy. Authors have studied the impact of introducing extended course content, interdisciplinary communications and feedback in teacher-student interaction. Computer training systems, $a$ semantic network, and statistical analysis were used as assessment methods. Research aim of this article offers an overview of methods of assessing quality of education and their comparison in order to select the best one for conducting a pedagogical experiment, which were used in Riga Technical University.
\end{abstract}

Keywords: educational process, learning quality assessment methods, pedagogical experiment.

\section{Introduction}

Education is one of the most important steps towards sustainable development, ensuring economic growth and social stability. Innovation activity and new production technologies are the key to quality education. However, accelerating the pace of technology updates leads to the need to introduce new forms and methods of teaching, as well as a new approach to the learning process. 
Due to the increasing pace of scientific and technological progress, there is a continuous increase in the volume and change in the content of knowledge and skills that modern specialists should possess, as a result of which the requirements for the quality of their training increase. However, the mismatch between the possibilities of traditional teaching methods and the amount of factual knowledge that modern society requires from the graduates of educational institutions indicates a problem in the system of modern higher education. Therefore, the issues of computer training and knowledge control are of interest of many scientists, both teachers and specialists in the field of information technology.

With the introduction of new educational standards (Statement of the Third Bologna Policy Forum, 2012), ensuring the interconnection of fundamental and practical training, technical universities need to update the content, forms, methods and teaching tools, as well as ensure control over the quality of education. In this context, the quality management of vocational education in a university should be considered as a single process of quality assurance, quality control and continuous improvement of applied teaching methods.

In the field of education to check the effectiveness of a pedagogical approach in solving the set task an experiment is planned and carried out. First of all, it is needed to analyse the problem and identify the participants of the experiment. Then it is necessary to form control and experimental groups of approximately equal numbers and levels of preparedness. Further, the researched pedagogical approach is implemented, the results obtained are studied and evaluated, and finally, conclusions are drawn.

There are a large number of different approaches to the organization of training and knowledge control, each of them has its advantages and disadvantages (Li \& Xiong, 2016), (Zhang, Fan, Fang, Chen, \& Wang, 2018), (Zhao \& Zhang, 2018).

The aim of this study is to present authors own practice and by using methods of assessing quality of education and their comparison which were used in Riga Technical University (RTU), select the best one for conducting a pedagogical experiment.

\section{Overview of the methods used in the Department of Software Engineering}

The academic staff of the Department of Software Engineering constantly analyses, improves and updates the content and forms of methods and tools for teaching students of RTU. There are many ways to evaluate the results of pedagogical experiments. To do this, it is necessary to organize the collection of statistical data, to develop methods for their analysis.

The main way to assess the impact of different approaches to the organization of the student learning process is the statistical processing of data 
using specific statistical methods. Statistical analysis allows you to identify the presence of the effect of a method used in learning, as well as to investigate the influence of the studied factor depending on its level. Using statistical analysis at the Department of "Software Engineering" of the RTU, we analysed the impact of computer-based learning and knowledge control systems such as Learning Management System (LMS), Intelligent Knowledge Assessment System (IKAS) and the electronic portal ORTUS on student performance (Prokofjeva, Zagulova, Katalnikova, \& Synytsya, 2018).

In the modern educational process, the role of students' independent work is increasing. Therefore, the urgent issue is the organization of students' independent work and the formation of skills of such work (Rupšienè \& Mažioniené, 2011). In this case, one of the difficult questions becomes the motivation of students, since self-study requires an active attitude of the student to the assimilation of new knowledge, that is, self-motivation. Therefore, students in the learning process were given the opportunity of their own free will to choose to use LMS and ORTUS systems or not.

An analysis of the results of academic performance and different approaches to organizing the learning process using LMS and ORTUS systems allowed authors to assess the possibilities of using these systems for self-study and selfcontrol of knowledge in a situation where their mandatory use is not declared in the presence and absence of motivation. To analyse the data, authors used correlation and one-way analysis of variance (ANOVA) followed by a posteriori analysis using the Tukey method for unequal groups (Tukey HSD for unequal N). At the same time, it was shown that students, who independently, of their own free will, without additional incentives, fully used the computer-based learning system and the knowledge control system, had better academic performance in the subject. As a motivating factor, the mark obtained in the tests was taken into account when receiving the final mark for the exam. That is, such an approach can contribute to the formation of self-study skills, which are so necessary for adaptation in the modern world.

Another approach was used by the authors in (Katalnikova, Novickis, \& Prokofyeva, 2016), (Katalnikova, Novickis, Prokofjeva, \& Schumann, 2017). Several study courses were supplemented with new content elements. During the experiment, the question arose of how to assess the quality of the course, the success of its modifications, when both the course content and teaching methods were changed, using not only experimental but also mathematical methods. It was decided to try to use such a tool as a semantic network, i.e., the task of assessing the quality of the training course was considered as the task of assessing the complexity of the semantic network displaying this course using the graph metrics such as height, edge density and diameter of the graph corresponding to this network. Unfortunately, this experience was unsuccessful. The authors did not 
succeed in obtaining a stable, reliable result; therefore, the authors used other methods in their further studies.

The Department of "Software Engineering" conducts classes on the study of programming, not only for computer scientists, but also for chemists, electricians, and mechatronics. The article "Structurization of courses at studying disciplines of programming” (Prokofjeva, Uhanova, Zavjalova, \& Katalnikova, 2015) proposed a methodology for structuring learning courses "Computer Learning" and "Programming Languages" for students of these professions. The courses provide not only the organization of practical work on the computer, but also familiarization of students with the principles of algorithmization of computing processes and technology for creating application programs. Traditionally each study course consists of three main components: theoretical part, laboratorypractical part and evaluation part. All these parts are obligatory and traditionally are taught in the higher education institutions. The authors of the article hypothesized that a balanced supplementing of courses with new content elements should significantly increase student performance, as well as the quality of training in these disciplines. To prove or disprove the hypothesis, an experiment was conducted at the faculty and statistics for five academic years were collected. All students are divided into two main groups: students who studied according to the traditional methodology and students whose training and knowledge testing was carried out according to the proposed methodology. The technology for assessing the quality of student training is based on taking into account the results of various educational and control works during a certain period of study. The grades obtained are generalized indicators of the quality of training. They allow to analyse the quality of education of individual students and academic groups (Grigorash \& Trubilin, 2013). The coefficients for assessing the quality of students' learning in the disciplines "Programming Languages" and "Computer Education" were determined. The results show that when teaching students according to the traditional scheme, the coefficient of assessing the quality of students' training is significantly lower than when applying the advanced teaching methods of these disciplines. Thus, a balanced addition of new substantive elements to the courses not only improves student performance, but also significantly improves the quality of training and knowledge control, which is an urgent task for the engineers in the formation of those skills and abilities that they will use in their future professional activities.

The higher education system is primarily aimed at ensuring high-quality education through the formation of competence in specialists. In the article "Some Aspects of Students' Professional Competence Formation on the Basis of Implementation of Interdisciplinary Links" (Prokofyeva, Katalnikova, \& Boltunova, 2019), the authors describe the possibilities of applying an interdisciplinary approach to the preparation of students of higher education 
institutions, allowing them to maximize the knowledge gained in previous disciplines and to orient in related areas of future professional activity. The preconditions for the application of such an approach are identified and the ways of implementing an interdisciplinary approach are considered, also its effect on increasing student results is shown. A pedagogical experiment was also conducted, where the coefficient of assessing the quality of student training was used. The results of the experiment convincingly show that the implementation of interdisciplinary links in the process of teaching students really motivates students and contributes to the improvement of the quality of education.

In the work "Feedback Method In Teacher-Student Interaction" (Prokofyeva, Zavjalova, \& Boltunova, 2019), the authors consider control as a mandatory component of the learning process, which is carried out at all stages of the educational work, provides feedback "teacher-student" and serves as the basis for improving the quality of training. Since the modern educational process is too formalized, the presence of feedback takes into account the characteristics of students, which allows to develop a personal approach and effectively organize learning sessions. It also contributes to the development of skills for selfeducational and professional activities. Stable contact between the teacher and the student affects the formation of the value system of the future specialist and, in turn, determines the professional level and the true authority of the teacher.

The article considers two feedback methods: questioning and testing. Considering the results of questionnaires and testing of students obtained in the first year of study, the teacher made adjustments to the process of teaching the subject "Computer science" in the next academic year, which allowed, without changing the course program, to "work out” weaknesses in students' knowledge and offer more clear examples, practical tasks, homework. As a result, grades for the exam in this subject are higher than in the first year. That is, feedback from students significantly helps to improve both the content of the course, the teaching methodology, and provides increased student achievement in the subject of "Computer Science".

\section{Advantages and disadvantages of the considered methods}

There are a large number of different approaches (methods) to assessing the quality of learning organization, each of them has its advantages and disadvantages. In the following table, the authors noted the features (characteristics) of some methods for assessing the quality of student learning (Table 1).

Currently, lecturers of the department use these methods to provide highquality training for students, stimulating their independent and creative educational activities. 
Thus, the conducted studies show that each method allows an objective assessment of students' activities, as well as raising responsibility for the results of their academic work.

Table 1 Characteristics of methods for assessing the quality of student learning

\begin{tabular}{|c|c|c|}
\hline Methods & Advantages & Disadvantages \\
\hline $\begin{array}{l}\text { Statistical } \\
\text { analysis }\end{array}$ & $\begin{array}{l}\text { Allows to identify the effects of } \\
\text { factors, patterns and relationships } \\
\text { between the studied factors and } \\
\text { parameters }\end{array}$ & $\begin{array}{l}\text { Errors of the 1st and 2nd kind, } \\
\text { taking into account falsely reliable } \\
\text { results (Wasserstein \& Lazar, 2016) } \\
\text { Instability of p-levels on equivalent } \\
\text { samples (Nuzzo, 2014). Possible } \\
\text { irreproducibility of the results, } \\
\text { which may be due to individual } \\
\text { characteristics of students and } \\
\text { changes in the learning process }\end{array}$ \\
\hline $\begin{array}{l}\text { Method for } \\
\text { assessing the } \\
\text { complexity } \\
\text { of the } \\
\text { semantic } \\
\text { networks }\end{array}$ & $\begin{array}{l}\text { The advantage of network models } \\
\text { is the visibility of the domain } \\
\text { description (Katalnikova } \\
\text { et al., 2017). Assessing the quality } \\
\text { of the learning course using } \\
\text { quantitative metrics of complexity } \\
\text { of the semantic web attracts with } \\
\text { the simplicity of the method and } \\
\text { ease of use }\end{array}$ & $\begin{array}{l}\text { Unfortunately, this method has a too } \\
\text { large assessment step; with small } \\
\text { changes in the learning course, this } \\
\text { method does not produce noticeable } \\
\text { changes in network characteristics }\end{array}$ \\
\hline $\begin{array}{l}\text { Quality } \\
\text { Assessment } \\
\text { Method }\end{array}$ & $\begin{array}{l}\text { The ability to evaluate both student } \\
\text { performance over a certain period, } \\
\text { and evaluating the effectiveness of } \\
\text { a particular academic structure, for } \\
\text { example, a department (Grigorash, } \\
\text { 2018); } \\
\text { The possibility of using, together } \\
\text { with other methods of improving } \\
\text { the educational process (for } \\
\text { example, a new course structure or } \\
\text { with an interdisciplinary approach) }\end{array}$ & $\begin{array}{l}\text { The most important drawback is the } \\
\text { average score, that is, the results of } \\
\text { the study are an average value }\end{array}$ \\
\hline $\begin{array}{l}\text { Questioning } \\
\text { Method }\end{array}$ & $\begin{array}{l}\text { The advantage of this method is } \\
\text { the presence of quick feedback, so } \\
\text { that lecturer can easily modify the } \\
\text { course according to the current } \\
\text { needs of students, without reducing } \\
\text { the quality of the course and not } \\
\text { losing sight of the overall goal }\end{array}$ & $\begin{array}{l}\text { One of the main shortcomings is the } \\
\text { subjectivity of the opinions } \\
\text { expressed. Errors in the preparation } \\
\text { of questionnaires. Violation of } \\
\text { external and internal validity } \\
\text { (Bernstein, 2018), (Gehlbach, } \\
\text { Robinson, Finefter-Rosenbluh, } \\
\text { Benshoof, \& Schneider, 2018) }\end{array}$ \\
\hline
\end{tabular}


SOCIETY. INTEGRATION. EDUCATION

Proceedings of the International Scientific Conference. Volume II, May $22^{\text {th }}-23^{\text {th }}, 2020.484-491$

\section{Conclusion}

The main task of modernization of higher education is the formation of an effective strategy to improve the quality of educational services. Obviously, separate, unsystematic methods are not effective. Only a comprehensive and holistic approach which takes into account the accumulated experience, can lead to tangible achievements in the field of improving the process of higher education and achieving competitive quality standards, for which it is necessary to solve the following problems:

1. With the help of the designed questionnaires carry out monitoring with a certain frequency,

2. Apply the method of testing students as a guarantor of the quality of assimilation of knowledge,

3. Apply the methods of mathematical statistics, quality and complexity assessment of the semantic network as a mechanism for coordination and interconnection of various methods,

4. Based on the creation of a unified system, continue the process of improving the development strategy of the pedagogical activity of the department in order to meet the needs of consumers of higher education and the compliance of learning with the needs of the modern labour market.

Further studies are related to the determination of the effectiveness of the lecturers of the department, their educational, methodological and scientific work.

\section{References}

Bernstein, J.L. (2018). Unifying SoTL Methodology: Internal and External Validity. Teaching \& Learning Inquiry, 2, 115-126.

Gehlbach, H., Robinson, C.D., Finefter-Rosenbluh, I., Benshoof, C., \& Schneider, J. (2018). Questionnaires as interventions: can taking a survey increase teachers' openness to student feedback surveys? Educational Psychology, 38(3), 350-367. DOI: 10.1080/01443410.2017.1349876

Grigorash, O. (2018). Sovremennye tehnologii ocenki jeffektivnosti raboty kafedry tehnicheskogo vuza. Cheboksary: Sreda. Retrieved from https://phsreda.com/epublications/e-publication-30.pdf

Grigorash, O., \& Trubilin, A. (2013). Sistema ocenki kachestva dejatel'nosti prepodavatelej i kafedry vuza. Polythematic network electronic journal of the Kuban State of Agrarian University (The science journal KubGAU). Krasnodar: KubGAU, 92(08).

Katalnikova, S., Novickis, L., \& Prokofyeva, N. (2016). Knowledge Representation in Intelligent Collaborative Educational Systems. 4th International Workshop on Intelligent Educational Systems, Technology-enhanced Learning and Technology Transfer Models (INTEL-EDU 2016). Prague, Czech Republic. 
Katalnikova, S., Novickis, L., Prokofjeva, N., \& Schumann, M. (2017). Issues of Upgrading Study Courses and Use of Semantic Networks as a Means for Their Evaluation. Procedia Computer Science, 104, 266.-271. DOI:10.1016/j.procs.2017.01.134

Li, M., \& Xiong, Y. (2016). Study on the quality control system of experiment teaching of Applied Chemistry Specialty. 5th International Conference on Social Science, Education and Humanities Research. DOI: 10.2991/ssehr-16.2016.240

Nuzzo, R. (2014). Scientific method: statistical errors. Nature News, 506, 150-152. DOI: 10.1038/506150a

Prokofyeva, N., Katalnikova, S., \& Boltunova, V. (2019). Some Aspects of Students' Professional Competence Formation on the Basis of Implementation of Interdisciplinary Links. In V. Uskov, R. Howlett, \& L Jain (Eds.), Smart Education and e-Learning 2019. Smart Innovation, Systems and Technologies. Singapore. Springer. DOI: https://doi.org/10.1007/978-981-13-8260-4_36

Prokofjeva, N., Uhanova, M., Zavjalova, O., \& Katalnikova, S. (2015). Structuration of Courses at Studying Disciplines of Programming. Proceedings of the 10th International Scientific and Practical Conference "Environment. Technology. Resources", 3, 159.-163. DOI: 10.17770/etr2015vol3.179

Prokofjeva, N., Zagulova, D., Katalnikova, S., \& Synytsya, K. (2018). Possible Uses of Computer Systems in University Training of IT Professionals. Society. Integration. Education. Proceedings of the International Scientific Conference, 5, 390-401. DOI:10.17770/sie2018vol1.3185

Prokofyeva, N., Zavjalova, O., \& Boltunova, V. (2019). Feedback Method in Lecturer-Student Interaction. Society. Integration. Education. Proceedings of the International Scientific Conference, 1, 442-448. DOI: http://dx.doi.org/10.17770/sie2019vol1.3791

Rupšienè, L., \& Mažionienè, A. (2011). Independent work at higher school from the viewpoint of social care teacher's management competencies development: students' opinion. Tiltai, 3(56), 151-158. (in Lithuanian).

Statement of the Third Bologna Policy Forum. (2012). European Ministers in charge of Higher Education: Making the Most of Our Potential: Consolidating the European Higher Education Area.

Wasserstein, R., \& Lazar, N. (2016). The ASA's Statement on p-Values: Context, Process, and Purpose. The American Statistician, 70(2), 129-133. DOI: 10.1080/00031305.2016.1154108

Zhang, J.H., Fan, J., Fang, M., Chen, W., \& Wang, C. (2018). How to Construct a Resonable Teaching Quality Assurance System in Universities. IEEE Asia Pacific Conference on Circuits and Systems (APCCAS), 350-353. DOI: 10.1109/APCCAS.2018.8605658

Zhao, H., \& Zhang, D. (2018). Application status and development trend of blending teaching mode: application analysis based on MOOC, microlecture and flipped classroom. 3rd International Conference on Modern Management, Education Technology, and Social Science (MMETSS 2018). 